\title{
UJI PERFORMANSI TEKNOLOGI RECIRCULATING AQUACULTURE SYSTEM (RAS) TERHADAP KONDISI KUALITAS AIR PADA PENDEDERAN LOBSTER PASIR Panulirus homarus
}

\author{
PERFORMANCE TEST OF RECIRCULATING AQUACULTURE SYSTEM (RAS) TECHNOLOGY \\ TO WATER QUALITY CONDITION IN SPINY LOBSTER Panulirus homarus NURSERY
}

\author{
Lolita Thesiana dan Amin Pamungkas \\ Pusat Pengkajian Perekayasaan Teknologi Kelautan Perikanan-Balitbang-KKP \\ Jl Pasir Putih I Ancol, Jakarta, Indonesia \\ E-mail: thesiana@yahoo.com
}

Diterima tanggal: 22 Januari 2015, diterima setelah perbaikan: 11 Juni 2015, disetujui tanggal: 26 Juni 2015

\begin{abstract}
ABSTRAK
Pendederan lobster Panulirus homarus dimaksudkan untuk memperoleh bibit yang adaptif dan seragam sebelum dibudidayakan dalam keramba. Pendederan lobster dapat dilakukan secara indoor dengan menggunakan teknologi Recirculating Aquaculture System (RAS). Penggunaan teknologi RAS dimaksudkan untuk mengontrol beberapa parameter kualitas air agar memenuhi syarat kualitas air untuk budidaya. Tujuan dari penelitian ini adalah menganalisis parameter kualitas air pada pendederan lobster Panulirus homarus dengan menggunakan teknologi RAS. Filter yang digunakan pada RAS ini disusun dari beberapa media yang terdiri dari susunan batu biocrystal, batu koral, zeolit dan karbon aktif. Parameter kualitas air yang diuji meliputi suhu, $\mathrm{pH}$, oksigen terlarut, $\mathrm{CO}_{2}$, nitrit, nitrat dan amonia. Secara keseluruhan, parameter kualitas air selama penelitian yang diuji, masih memenuhi syarat untuk kegiatan pendederan lobster Panulirus homarus.
\end{abstract}

Kata kunci: RAS, kualitas air, pendederan, lobster, Panulirus homarus

\section{ABSTRACT}

Panulirus homarus seed nursery is an effort to yield adaptive and uniform quality lobster seed, prior to seacages rearing. Land based spiny lobster nursery can use Recirculating Aquaculture System technology (RAS). RAS technology is intended to control several water quality parameter, in order to meet the water quality requirements for lobster seed cultivation. The purpose of this study was to analyze water quality parameters in Panulirus homarus nursery using RAS technology. Filters used in RAS are composed of biocrystal stone, coral, zeolites and activated carbon. Water quality parameters recorded include temperature, $\mathrm{pH}$, dissolved oxygen, $\mathrm{CO}_{2}$, nitrite, nitrate and ammonia. Overall, water quality parameters during the study were qualify for Panulirus homarus nursery activities.

Keywords: RAS, water quality, nursery, lobster, Panulirus homarus

\section{PENDAHULUAN}

Recirculating Aquaculture Systems (RAS) adalah sebuah sistem produksi perikanan yang mengolah kembali air yang digunakan agar memenuhi syarat kualitas air untuk kegiatan budidaya (P3TKP, 2013). Teknologi RAS merupakan salah satu pilihan teknologi yang banyak digunakan untuk kegiatan budidaya perikanan secara intensif beberapa tahun ini. Aplikasi dan pengembangan teknologi RAS pada berbagai jenis ikan telah banyak dilakukan oleh Norwegia selama kurun waktu 20-30 tahun ini. Beberapa jenis ikan yang dibudidayakan adalah Salmon (Salmo salar), Rainbow Trout (Oncorhynchus mykiss), Sidat (Anguilla anguilla), Pike Perch (Stizostedion lucioperca), Arctic Char (Salvelinus alpinus), Sturgeon (order Acipenseriformes), Nila (Oreochromis niloticus), dan Lobster Homarus 
gammarus (Dalsgaard, Lund, Thorarinsdottir, Drengstig, Arvonen, \& Pedersen, 2013).

Kegiatan budidaya lobster Homarus gammarus skala besar di Norwegia telah menggunakan landbased RAS untuk memproduksi lobster ukuran konsumsi. Fasilitas budidaya ini mempunyai persediaan induk dan pembenihan untuk memproduksi bibit juvenil lobster tingkat IV. Sistem yang digunakan pada pembesaran lobster adalah 'single cage technology with moving bed biofilters', dimana sistem resirkulasi dirancang secara intensif untuk manajemen penggunaan air (Drengstig dan Bergheim, 2013).

Kegiatan budidaya lobster sedang marak dilakukan oleh beberapa negara ASEAN. Lobster yang umum dibudidayakan adalah lobster pasir Panulirus homarus. Pada budidaya lobster di Vietnam, benih lobster yang tertangkap dipelihara selama 30-60 hari terlebih dahulu, sebelum dibudidaya dalam keramba di laut (Chau, Ngoc, \& Nhan, 2008). Budidaya pembesaran lobster di Indonesia menggunakan keramba jaring apung telah banyak dilakukan di kawasan Pelabuhan Ratu dan Lombok. Salah satu permasalahan dalam budidaya pembesaran lobster ini adalah rendahnya kelangsungan hidup benih lobster yang dibudidayakan. Hal ini karena benih yang digunakan tidak melalui proses aklimatisasi terlebih dahulu seperti di Vietnam. Selain itu, pada kegiatan pembesaran lobster ini, benih yang ditebar memiliki ukuran sangat beragam. Keberagaman ukuran benih yang digunakan menyebabkan potensi terjadinya kanibalisme semakin tinggi (Johnston et al., 2006). Larva lobster bersifat sangat kanibal karena ketika menemukan sebuah objek mereka akan menguji apakah benda tersebut dapat dimakan atau tidak (Burton, 2003). Tingkat kematian benih lobster yang tinggi tentunya dapat mengurangi keuntungan pembudidaya. Salah satu cara untuk mengatasi permasalahan tersebut, maka perlu dilakukan kegiatan pendederan benih lobster, sebelum dilakukan penebaran di keramba.

Kegiatan pendederan lobster air laut, dapat dilakukan secara indoor menggunakan teknologi RAS. Penggunaan RAS secara intensif dapat mengurangi secara signifikan konsumsi air dan konsentrasi nutrien melalui perbaikan dan pengembangan teknologi secara berkelanjutan.
RAS dapat digunakan untuk mengontrol beberapa parameter kualitas air penting seperti oksigen terlarut, karbon dioksida, amonia, nitrit, nitrat, $\mathrm{pH}$, salinitas, dan padatan tersuspensi. Hal ini memungkinkan terciptanya kondisi pemeliharaan yang baik untuk pertumbuhan dan pemanfaatan pakan yang lebih optimal (Dalsgaard et al., 2013). Tujuan dari penelitian ini adalah untuk menganalisis parameter kualitas air pada pendederan lobster Panulirus homarus dengan menggunakan teknologi RAS.

\section{BAHAN DAN METODE}

Penelitian dilakukan pada bulan November 2013 sampai dengan Januari 2014, di Laboratorium Fakultas Perikanan dan Ilmu Kelautan IPB, Jalan Pasir Putih 1 Ancol Timur, Jakarta Utara.

Benih lobster yang digunakan dalam penelitian ini didapat dari wilayah Lombok Selatan sebanyak 760 ekor. Berat benih lobster yang digunakan dalam peneltian ini 2,12 $\pm 0,02$ gram/ekor. Jenis lobster yang digunakan adalah lobster pasir Panulirus homarus. Padat tebar benih lobster dalam penelitian ini adalah 95 ekor/ $\mathrm{m}^{2}$. Selama penelitian, pemberian pakan ikan teri sebesar $10 \%$ dilakukan satu kali dalam sehari (Johnston et al., 2006). Pemeliharaan benih selama penelitian dilakukan selama 70 hari.

Pada penelitian ini digunakan 10 bak. 8 buah bak digunakan untuk perlakuan kemudian 2 bak lainnya masing-masing digunakan sebagai tampungan effluen dan tampungan hasil filter. 9 bak percobaan terbuat dari plastik, masing-masing berdimensi 1,2 × $0,95 \times 1 \mathrm{~m}$ dan 1 bak fiber bentuk lingkaran dengan diameter $1,5 \mathrm{~m}$ dan tinggi 0,75 m. Pada penelitian ini, digunakan sistem resirkulasi, dengan mengoperasikan 2 pompa submersible masing-masing kapasitas 5500 L/jam (Gambar 1). Aerasi dilakukan dengan menggunakan aerator jenis diffuser, dengan jumlah titik aerasi sebanyak 3 titik pada masing-masing bak perlakuan. Filter yang digunakan tersusun dari beberapa media yang terdiri dari batu biocrystal sebanyak 71,0 $\mathrm{cm}^{3}$, batu koral sebanyak 71,5 $\mathrm{cm}^{3}$, zeolit sebanyak 271,1 $\mathrm{cm}^{3}$ dan karbon aktif sebanyak 480,3 $\mathrm{cm}^{3}$ (Gambar 2). Jenis perlakuan pada bak pendederan adalah menggunakan shelter jaring, lubang angin, paralon dan tanpa shelter. 
Pengujian parameter fisika-kimia air dilakukan untuk mengetahui kinerja RAS yang digunakan. Pengujian parameter fisika air dilakukan setiap hari meliputi pengujian parameter $\mathrm{pH}$, salinitas, temperatur dan DO. Pengamatan parameter kimia air dilakukan pada hari ke-0, 1, 3, 7, kemudian setiap 7 hari. Pengujian parameter kimia meliputi parameter amonia, nitrit, nitrat, $\mathrm{CO}_{2}$. Metode pengujian parameter fisika-kimia air mengacu pada APHA (1990).

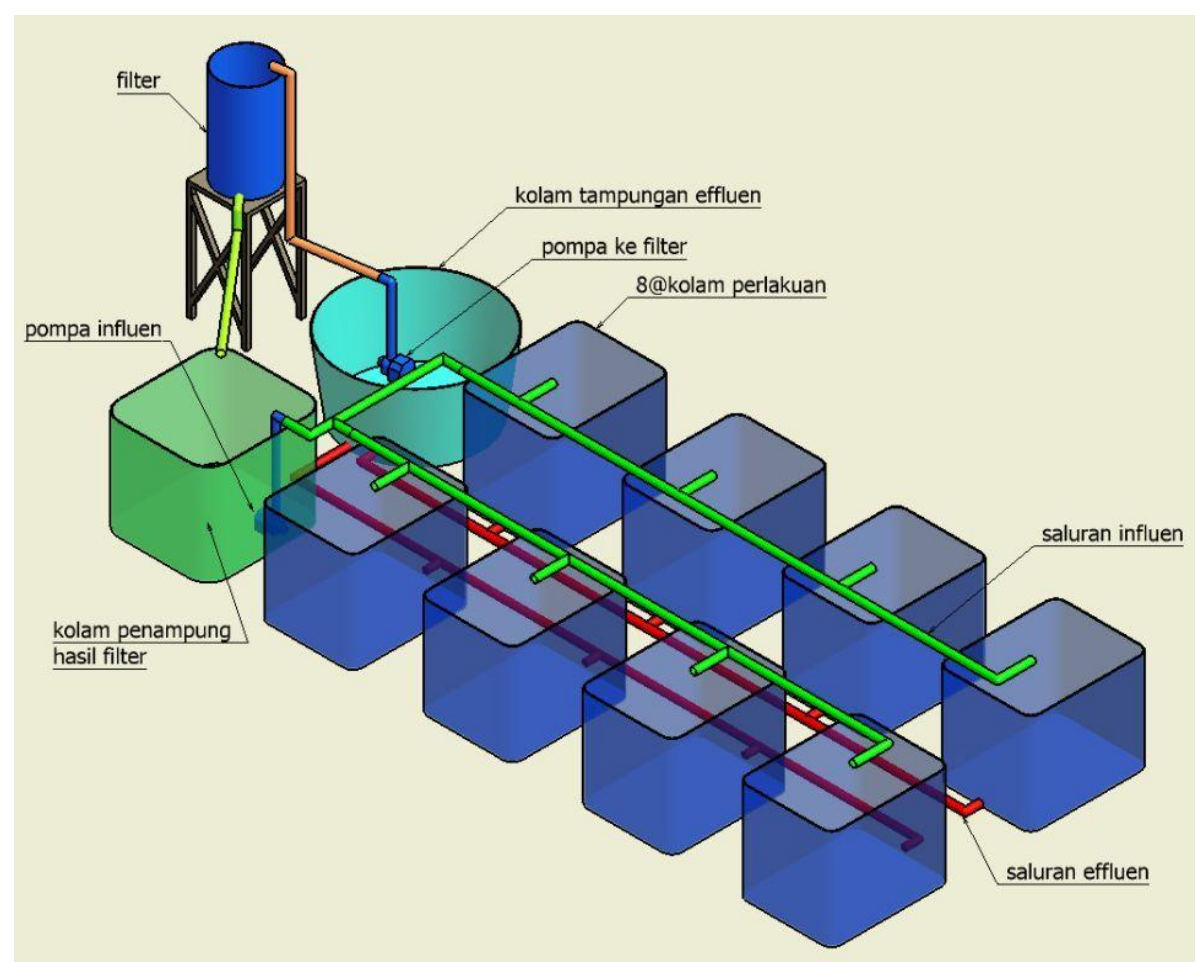

Gambar 1. Instalasi RAS pada pendederan lobster Panulirus homarus Figure 1. RAS installation of lobster Panulirus homarus nursery Sumber: Koleksi pribadi

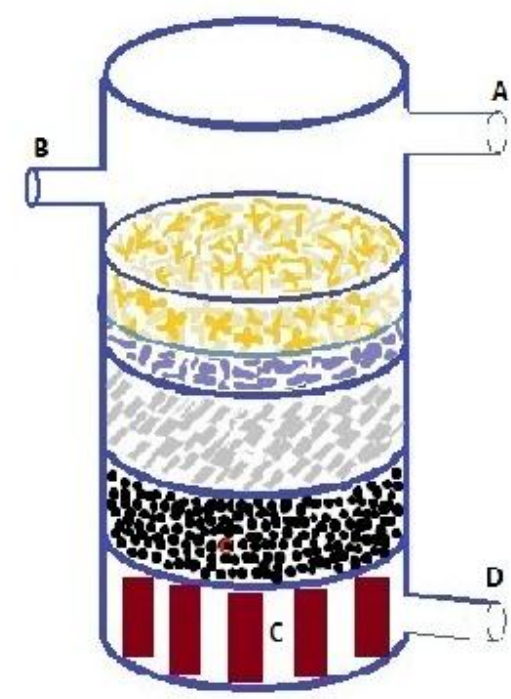

$$
\begin{aligned}
& \text { Keterangan: } \\
& \text { A } \quad=\text { Inlet } \\
& \text { B } \quad=\text { Overflow } \\
& \text { C } \quad=\text { Ruang penampung filtrasi } \\
& \text { D } \quad=\text { Outlet }
\end{aligned}
$$

Gambar 2. Susunan media filter Figure 2. Filter media composition Sumber: Koleksi pribadi

\footnotetext{
Uji Performansi Teknologi Recirculating Aquaculture System (RAS) Terhadap Kondisi Kualitas Air pada Pendederan Lobster Pasir Panulirus homarus - Lolita Thesiana dan Amin Pamungkas
} 


\section{HASIL DAN PEMBAHASAN}

\section{Hasil}

Suhu selama penelitian cenderung fluktuatif berkisar antara 27,33-28,88 ${ }^{\circ} \mathrm{C} . \quad \mathrm{pH}$ selama penelitian berkisar antara 7,07-7,86. Pada awal penelitian $\mathrm{pH}$ cenderung lebih tinggi dibanding selama penelitan. Oksigen terlarut (DO) selama
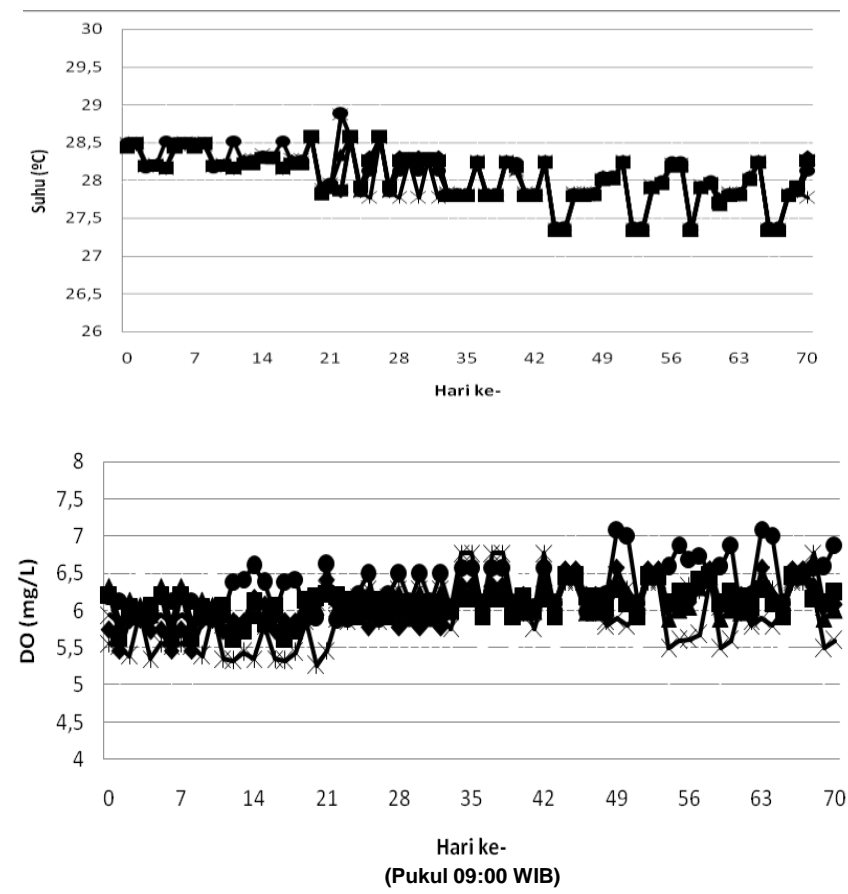

Keterangan:

- Bak perlakuan dengan shelter jaring

- Bak perlakuan menggunakan shelter paralon

- Bak perlakuan menggunakan shelter lubang angin

$\leftarrow$ Bak perlakuan tanpa shelter

$\rightarrow$ Effluen

Filtrat penelitian pada pukul 09.00 WIB cenderung fluktuatif berkisar antara 5,26-7,09 $\mathrm{mg} / \mathrm{L}$, dan pada pukul 16.00 WIB berkisar antara 5,15-7,17 $\mathrm{mg} / \mathrm{L}$. Tren kondisi oksigen terlarut pada awal penelitian sampai akhir penelitian mengalami sedikit peningkatan. Kondisi suhu, $\mathrm{pH}$ dan oksigen terlarut selama penelitian dapat dilihat pada Gambar 3.
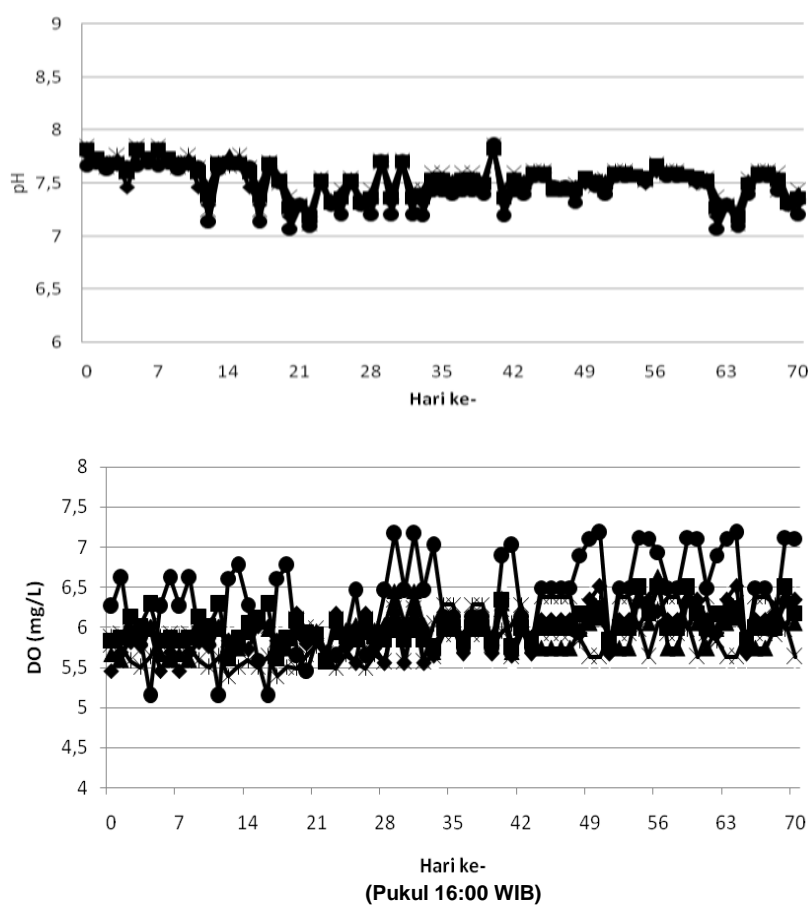

Gambar 3. Parameter suhu, $\mathrm{pH}$ dan oksigen terlarut selama penelitian

Figure 3. Temperature, $p H$ and dissolved oxygen parameter throughout the study Sumber: Hasil pengolahan data

Salinitas selama penelitian berkisar antara 34,1437,71 ppt. Kondisi salinitas cenderung mengalami kenaikan dari awal penelitian sampai akhir penelitian. Karbon dioksida $\left(\mathrm{CO}_{2}\right)$ selama penelitian berkisar antara 0,39-5,19 mg/L. Kondisi $\mathrm{CO}_{2}$ menunjukkan kecenderungan penurunan dari awal penelitian sampai akhir penelitian. Nitrit selama penelitian berkisar antara $0,22-3,14 \mathrm{mg} / \mathrm{L}$. Grafik nitrit selama penelitian mempunyai kecenderungan naik kemudian mengalami penurunan. Kondisi nitrat selama penelitian berkisar antara $0,11 \times 10^{-1}-6,78 \mathrm{mg} / \mathrm{L}$. Tren grafik menunjukkan, pada awal penelitian (sampai hari ke-21) konsentrasi nitrat mengalami peningkatan perlahan. Konsentrasi nitrat kemudian cenderung mengalami peningkatan sampai akhir penelitian. Kondisi amonia selama penelitian berkisar antara $0,67 \times 10^{-3}-0,55 \times 10^{-1} \mathrm{mg} / \mathrm{L}$. Tren grafik amonia, pada awal penelitian cukup rendah, berkisar antara $0,67 \times 10^{-3}-0,15 \times 10^{-2}$ (hari ke-0 sampai 14 ). Pada hari ke-21 sampai 35, konsentrasi amonia mengalami peningkatan. Konsentrasi amonia kemudian cenderung mengalami penurunan sampai pada akhir penelitian. Kondisi salinitas, $\mathrm{CO}_{2}$, nitrit, nitrat, dan amonia selama penelitian dapat dilihat pada Gambar 4. 

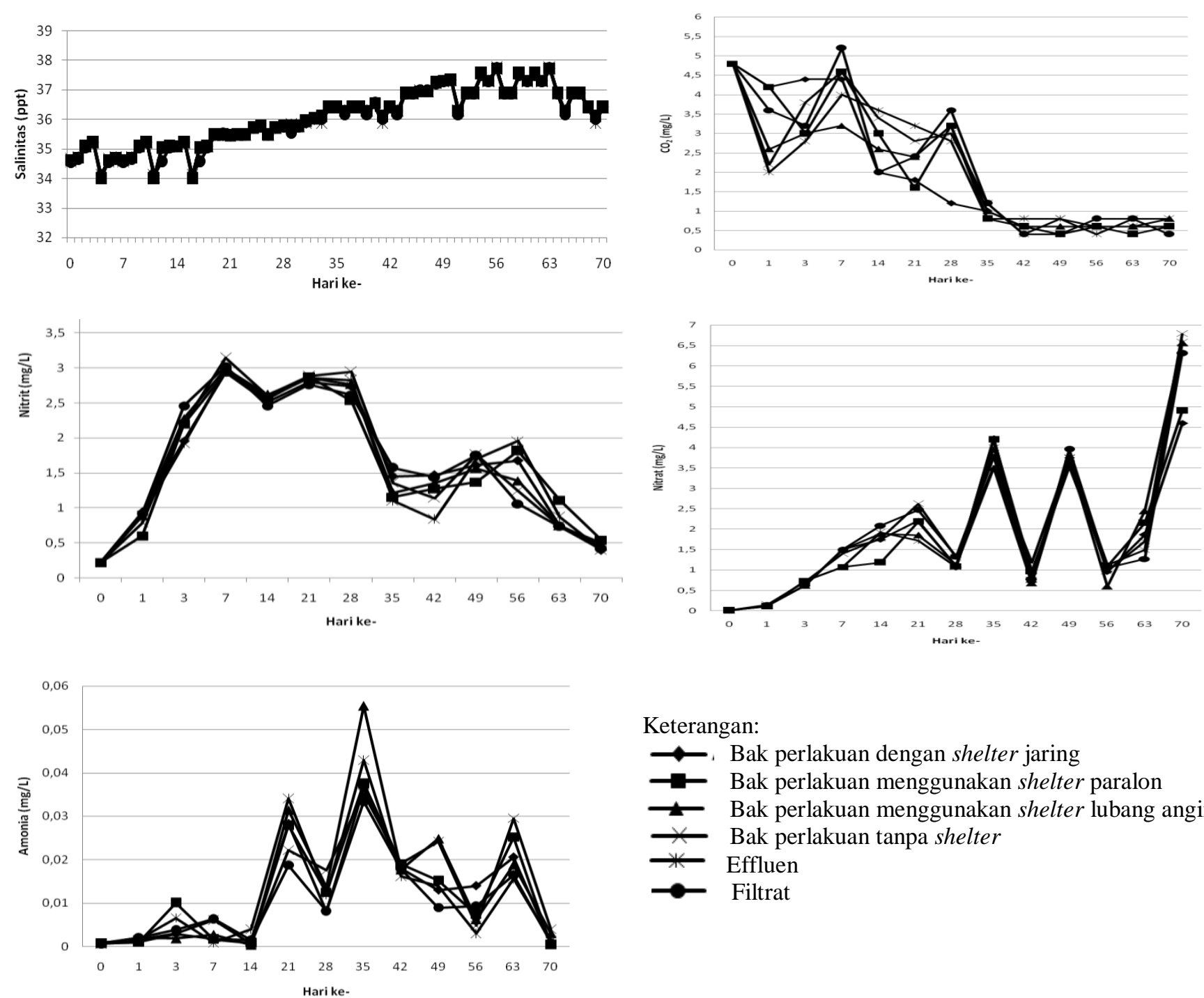

Keterangan:

ㄴ. Bak perlakuan dengan shelter jaring

$\rightarrow$ Bak perlakuan menggunakan shelter paralon

- Bak perlakuan menggunakan shelter lubang angin

$\longleftarrow$ Bak perlakuan tanpa shelter

$\rightarrow$ Effluen

Gambar 4. Parameter salinitas, $\mathrm{CO}_{2}$, nitrit, nitrat, dan amonia selama penelitian Figure 4. Salinity, $\mathrm{CO}_{2}$, nitrite, nitrate and Ammoia parameter throughout the study Sumber: Hasil pengolahan data

\section{Pembahasan}

Batu koral pada filter yang mengandung kapur berfungsi untuk mempertahankan $\mathrm{pH}$ selama proses pemeliharaan/pendederan. Filter fisik digunakan untuk memisahkan padatan dari air secara fisika (berdasarkan ukuran) dengan cara menangkap atau menyaring sehingga kandungan bahan tersebut menjadi berkurang. Fungsi dari filter fisik adalah untuk menurunkan turbiditas di air yang disebabkan oleh mikroorganisme dan partikel lain, untuk menurunkan tingkat koloid organik, dan untuk menyingkirkan detritus dari filter biologi. Meskipun filter fisik dapat memisahkan partikel tersuspensi secara efisien, namun tidak efektif untuk memisahkan partikelpartikel yang terlarut (Yudha, 2009).

Karbon aktif berfungsi sebagai filter kimiawi. Karbon aktif digunakan untuk menyaring dan menghilangkan klorin, sedimen, bau dan senyawa organik Volatile Organic Compounds atau (VOC) dari air (Endarko et al., 2013). Ukuran partikel dan luas permukaan merupakan hal yang penting dalam karbon aktif. Ukuran partikel karbon aktif mempengaruhi kecepatan adsorpsi, tetapi tidak mempengaruhi kapasitas adsorpsi yang berhubungan dengan luas permukaan karbon. Luas permukaan total mempengaruhi kapasitas adsorpsi

Uji Performansi Teknologi Recirculating Aquaculture System (RAS) Terhadap Kondisi Kualitas Air pada Pendederan Lobster Pasir Panulirus homarus - Lolita Thesiana dan Amin Pamungkas 
total sehingga meningkatkan efektifitas karbon aktif dalam penyisihan senyawa organik dalam air buangan. Ukuran partikel tidak terlalu mempengaruhi luas permukaan total sebagian besar meliputi pori-pori partikel karbon. Struktur pori-pori karbon aktif mempengaruhi perbandingan antara luas permukaan dan ukuran partikel (Kasam, Yulianto dan Sukma, 2005). Adsorpsi umumnya digunakan untuk menghilangkan klorin dan kotoran organik. Hal ini dilakukan biasanya dengan karbon aktif granular (APHA, 1999).

Sumber amonia di perairan adalah pemecahan nitrogen organik (protein dan urea) dan nitrogen anorganik oleh mikroba dan jamur yang terdapat di dalam tanah dan air, yang berasal dari dekomposisi bahan organik (buangan metabolisme, sisa pakan) (Effendi, 2003). RAS mengandalkan nitrifikasi untuk mengkonversi amonia dan nitrit yang bersifat toksik menjadi nitrat. Nitrifikasi dapat berlangsung dalam biofilter oleh bakteri nitrifikasi. Kegagalan dalam biofilter dapat menghasilkan amonia atau nitrit yang sangat tinggi, yang keduanya beracun untuk hewan air dan dapat menyebabkan masalah kesehatan, menekan pertumbuhan, dan menyebabkan kematian (Kuhn et al., 2010). Penggunaan biocrystal dimaksudkan sebagai media biofilter, untuk tempat menempelnya bakteri nitirifikasi.

Zeolit berfungsi sebagai filter kimia. Zeolit bekerja dengan memanfaatkan kemampuan pertukaran ion. Zeolit adalah penukar kation yang efektif, yang memiliki nilai kemampuan tukar kation (KTK) sebesar 200-500 $\mathrm{cmol}_{\mathrm{c}} / \mathrm{kg}$. Terdapat berbagai macam zeolit dengan klinoptilolit memiliki afinitas yang tinggi terhadap amoiak dan telah berhasil digunakan sebagai pembersih amoniak pada sistem akuakultur air tawar (Silaban, et al., 2012). Ketika air buangan melewati zat ini, ion-ion tertentu pada air buangan tersebut melakukan pertukaran dengan ion-ion pada zat tersebut, karena memiliki afinitas yang kuat terhadap zat tersebut.

Suhu selama penelitian sangat fluktuatif. Hal ini disebabkan pengaruh cuaca pada saat penelitian. Apabila cuaca hujan maka suhu udara dalam ruang menjadi lebih rendah, sehingga menyebabkan temperatur air mengalami penurunan, demikian juga sebaliknya. Menurut Phillips dan Kittaka (2000), pertumbuhan tercepat pada juvenil Panulirus homarus terdapat pada suhu sebesar 28
${ }^{\circ} \mathrm{C}$, dengan panjang karapaks yang dicapai sebesar $60 \mathrm{~mm}$ dalam waktu 18 bulan. Kondisi suhu selama penelitian masih sesuai untuk pertumbuhan lobster, karena berada pada rentang 27,33-28,88 ${ }^{\circ} \mathrm{C}$.

Menurut Boyd dan Tucker (1998), nilai pH yang disarankan untuk kegiatan akuakultur berkisar antara 6,5-9, sedangkan $\mathrm{pH}$ yang optimum untuk biota laut berkisar antara 7,5-8,5. Crustacea pada perairan payau umumnya mempunyai nilai toleransi $\mathrm{pH}$ yang lebih luas. Penelitian pada udang panaeid menunjukkan $\mathrm{pH}$ yang optimum untuk pertumbuhan berkisar antara 5,5-8,5. Menurut Wickins dan Lee (2002), nilai pH yang disarankan untuk lobster clawed dan lobster spinny masingmasing sebesar 7,8-8,2 dan 8,0-8,5. Secara keseluruhan, nilai $\mathrm{pH}$ masih sesuai untuk pendederan lobster karena masih berada pada kisaran 7,07-7,86.

Kondisi oksigen terlarut pada pukul 09.00 WIB mempunyai kecenderungan lebih rendah dibanding pada pukul 16.00 WIB. Hal ini karena adanya aktifitas fotosintesis fitoplankton pada siang hari, sehingga konsentrasi oksigen terlarut mengalami peningkatan. Tren oksigen terlarut selama peneltian menunjukkan, konsentrasi oksigen yang terdapat pada filtrat relatif lebih tinggi dibandingkan pada bak perlakuan dan effluen. Hal ini, disebabkan pada filtrat, air telah mengalami aerasi selama kontak dengan media filter yang digunakan, sehingga terjadi peningkatan konsentrasi oksigen terlarut. Selain itu, konsumsi oksigen terlarut oleh benih lobster pada bak perlakuan, menyebabkan level oksigen terlarut mengalami penurunan dieffluen. Menurut Boyd dan Tucker (1998), konsentrasi oksigen terlarut yang disarankan untuk kegiatan perikanan adalah > $5 \mathrm{mg} / \mathrm{L}$. Tingkat konsumsi oksigen terlarut oleh lobster dipengaruhi oleh berat, temperatur dan salinitas. Pada juvenil lobster Panulirus japanicus, tingkat konsumsi oksigen terlarut pada saat istirahat adalah sekitar $0,02 \mathrm{mgO} /$ berat badan/jam (suhu $12{ }^{\circ} \mathrm{C}$ ) dan $0,11 \mathrm{mgO}_{2} /$ berat badan/jam (suhu $27{ }^{\circ} \mathrm{C}$ ) (Phillips dan Kittaka, 2000). Kondisi oksigen terlarut selama penelitian masih sesuai untuk syarat optimal lobster tumbuh karena berada pada kisaran $>5 \mathrm{mg} / \mathrm{L}$.

Kondisi salinitas yang terukur cenderung mengalami peningkatan karena adanya proses 
evaporasi air bak pemeliharaan, sehingga volume air mengalami penurunan tetapi kandungan total padatan terlarut tetap. Namun secara keseluruhan nilai salinitas tersebut, masih sesuai untuk kehidupan lobster. Menurut Phillips dan Kittaka (2000), juvenil lobster $P$. polyphagus dan $P$. Cygnus mempunyai toleransi rentang salinitas yang cukup luas, yaitu masing-masing sebesar 1750 dan 25-45 ppt. Kondisi salinitas optimal pada lobster spinny dilaporkan pada kisaran 32-36 ppt (Wickins dan Lee, 2002). Salinitas selama penelitian masih memenuhi syarat untuk kehidupan lobster karena masih berada pada kisaran 34,14-37,71 ppt.

Karbondioksida bebas dapat memberikan pengaruh yang merugikan pada ikan yang dipelihara jika konsentrasinya bertambah besar pada saat oksigen terlarut rendah. Kandungan $\mathrm{CO}_{2}$ bebas sekitar 12 $\mathrm{mg} / \mathrm{L}$ dapat menyebabkan stres pada ikan, sedangkan pada konsentrasi $30 \mathrm{mg} / \mathrm{L}$, menyebabkan beberapa jenis ikan mengalami kematian. Penelitian lain menunjukkan, konsentrasi $\mathrm{CO}_{2}$ yang disarankan untuk budidaya lobster air tawar adalah $<5 \mathrm{mg} / \mathrm{L}$ (Boyd dan Tucker, 1998). Secara keseluruhan konsentrasi $\mathrm{CO}_{2}$ selama penelitian masih sesuai untuk kehidupan lobster karena masih $<5 \mathrm{mg} / \mathrm{L}$. Tren grafik $\mathrm{CO}_{2}$ selama penelitian mempunyai kecenderungan penurunan. Pada awal penelitian konsentrasi $\mathrm{CO}_{2}$ relatif lebih tinggi. Hal ini disebabkan kemungkinan lobster mengalami tingkat stres yang lebih tinggi di awal penelitian karena belum beradaptasi, sehingga produk sisa metabolisme seperti $\mathrm{CO}_{2}$ yang dihasilkan juga mengalami peningkatan. Penurunan $\mathrm{CO}_{2}$ selama penelitian ini juga berkaitan dengan tingkat kelangsungan hidup lobster yang dipelihara. Semakin lama waktu penelitian, tingkat kelangsungan hidup juga akan semakin rendah, sehingga konsentrasi $\mathrm{CO}_{2}$ yang dihasilkan juga semakin rendah.

Kondisi nitrit selama penelitian berkisar antara 0,22-3,14 mg/L. Secara keseluruhan konsentrasi nitrit selama penelitian masih sesuai untuk kehidupan lobster. Menurut Drengstig dan Bergheim (2013), kandungan nitrit yang disarankan pada budidaya lobster Homarus gammarus menggunakan sistem resirkulasi adalah $<5 \mathrm{mg} / \mathrm{l}$. Penelitian lain menunjukkan, juvenil $P$. monodon mempunyai toleransi nitrit pada konsentrasi sebesar 3,8 $\mathrm{mg} / \mathrm{L}$ dengan salinitas 20 ppt (Boyd dan Tucker, 1998). Tren grafik nitrit selama penelitian mempunyai kecenderungan naik kemudian mengalami penurunan. Pada penelitian sampai dengan hari ke-28, konsentrasi nitrit mengalami kenaikan. Hal ini disebabkan adanya akumulasi sisa pakan dan feses lobster, sementara bakteri pengkonversi nitrit menjadi nitrat belum terbentuk dengan baik, sehingga menyebabkan konsentrasi nitrit mengalami peningkatan. Pada hari ke-35 sampai akhir penelitian, konsentrasi nitrit cenderung mengalami penurunan. Hal ini menunjukkan, konversi nitrit menjadi nitrat oleh bakteri Nitrobacter mulai berjalan.

Ion nitrat dibentuk oleh oksidasi lengkap dari ion amonium oleh mikroorganisme yang ada di tanah ataupun di dalam air atau akibat dari proses nitrifikasi amonia. Bakteri yang berperan dalam proses nitrifikasi untuk mengubah nitrit menjadi nitrat adalah Nitrobacter. Bakteri tertentu mungkin pula mengubah nitrat menjadi nitrogen bebas $\left(\mathrm{N}_{2}\right)$ yang dapat terlepas dari sistem sebagai gas (Spotte, 1996). Secara keseluruhan konsentrasi nitrat selama penelitian masih sesuai untuk kehidupan lobster karena berada pada kisaran $0,11 \times 10^{-1}-6$, $78 \mathrm{mg} / \mathrm{L}$. Pada budidaya lobster J. Edwardsii menggunakan sistem resirkulasi (Phillips dan Kittaka, 2000) dan budidaya lobster spinny (Wickins dan Lee, 2002), konsentrasi nitrat yang disarankan sebaiknya kurang dari $100 \mathrm{mg} / \mathrm{L}$.

Tren grafik menunjukkan, pada awal penelitian (sampai hari ke-21) konsentrasi nitrat mengalami peningkatan perlahan. Konsentrasi nitrat kemudian cenderung mengalami peningkatan sampai akhir penelitian, meskipun fluktuatif. Peningkatan konsentrasi nitrat ini menunjukkan proses nitrifikasi oleh bakteri telah berjalan. Menurut Boyd dan Tucker (1998), nitrifikasi adalah oksidasi berurutan amonia menjadi nitrat yang dilakukan oleh dua kelompok bakteri kemoautotrof dalam kondisi aerobik. Proses nitrifikasi berlangsung melalui persamaan reaksi sebagai berikut:

$$
\begin{aligned}
& \mathrm{NH}_{4}^{+}+1,5 \mathrm{O}_{2} \longrightarrow \mathrm{NO}_{2}^{-}+2 \mathrm{H}^{+}+\mathrm{H}_{2} \mathrm{O} \\
& \text { (dibantu Nitrosomonas) } \\
& \mathrm{NO}_{2}{ }^{-}+0,5 \mathrm{O}_{2} \longrightarrow \mathrm{NO}_{3} \\
& \text { (dibantu Nitrobacter). }
\end{aligned}
$$


Sesuai dengan persamaan (1) di atas, amonia dikonversi menjadi nitrit oleh bakteri Nitrosomas. Nitrit kemudian dikonversi menjadi nitrat oleh bakteri Nitrobacter. Nitrifikasi menyebabkan kadar amonia dalam air mengalami penurunan, dan konsentrasi nitrat mengalami peningkatan.

Amonia bebas $\left(\mathrm{NH}_{3}\right)$ yang tidak terionisasi (unionized) bersifat toksik terhadap organisme akuatik. Amonia lebih toksik saat kandungan oksigen terlarut turun. Konsentrasi sublethal dari $\mathrm{NH}_{3}$ menyebabkan perubahan patologi pada organ dan membran ikan (Boyd dan Tucker, 1998). Pada crustacea, amonia menyumbang $60 \%$ dari total nitrogen yang dieksresikan. Tingkat ekskresi dipengaruhi oleh pakan, temperatur, berat, level nutrien, salinitas, moulting, dan konsentrasi oksigen ambien (Phillips dan Kittaka, 2000). Kondisi amonia selama penelitian berkisar antara $0,67 \times 10^{-3}-0,55 \times 10^{-1} \mathrm{mg} / \mathrm{L}$. Secara keseluruhan, konsentrasi amonia tersebut masih memenuhi syarat untuk kehidupan lobster. Pada budidaya lobster J. Edwardsii menggunakan sistem resirkulasi (Phillips dan Kittaka, 2000), dan lobster spinny (Wickins dan Lee, 2002), konsentrasi amonia disarankan tidak lebih dari $0,1 \mathrm{mg} / \mathrm{L}$.

Tren grafik amonia, pada awal penelitian cukup rendah, berkisar antara $0,67 \times 10^{-3}-0,15 \times 10^{-2}$ (hari ke-0 sampai 14). Hal tersebut menunjukkan, ekskresi amonia oleh lobster (sisa pakan dan feses) belum banyak terakumulasi di air. Pada hari ke-21 sampai 35, konsentrasi amonia mengalami peningkatan, sebagai indikasi meningkatnya akumulasi buangan sisa pakan dan feses. Konsentrasi amonia kemudian cenderung mengalami penurunan sampai pada akhir penelitian. Hal ini disebabkan, proses nitrifikasi, yaitu konversi amonia menjadi nitrit dan nitrat oleh bakteri mulai berjalan, sehingga konsentrasi amonia mengalami penurunan.

\section{KESIMPULAN DAN SARAN}

\section{Kesimpulan}

Penggunaan teknologi Recirculating Aquaculture System (RAS) dengan menggunakan filter dari kombinasi susunan biocrystal, batu koral, zeolit dan karbon aktif, mampu menghasilkan kualitas air yang memenuhi syarat untuk budidaya pendederan lobster Panulirus homarus.

\section{Saran}

Perlunya dilakukan kajian tentang standar desain, komposisi, dimensi dan analisis ekonomi RAS untuk pendederan budidaya lobster.

\section{UCAPAN TERIMA KASIH}

Ucapan terima kasih dan penghargaan diberikan kepada bapak Eddy Supriyono dan Kukuh Adiyana atas bimbingannya dalam penyusunan karya tulis ilmiah ini. Ucapan terima kasih juga disampaikan kepada KKP yang telah memberikan pendanaan dari sumber APBN 2013 untuk terlaksananya penelitian ini.

\section{DAFTAR PUSTAKA}

[APHA] American Public Health Association. (1990). Standard methods for the examination of water and wastewater. $20^{\text {th }}$ edition. Washington DC (US): APHA Pr.

[APHA] American Public Health Association. (1999). Standard methods for the examination of water and wastewater. Washington DC (US): APHA $\operatorname{Pr}$

Boyd, C.E., \& Tucker, CS. (1998). Pond aquaculture water quality management. New York (US): Springer Science+Business Media.

Burton, C.A. (2003). Lobster hatcheries and stocking programmes: An introductory manual. Sea Fish Industry Authority Aquaculture Development Service. Seafish Report SR552. ISBN: 0903941 $66 \mathrm{X}$.

Chau, N.M., Ngoc, N.T.B., \& Nhan, L.T. (2008). Effect of different types of shelter on growth and survival of Panulirus ornatus Juveniles. Di dalam: Williams KC, editor. Spiny Lobster aquaculture in the Asia-Pacific region; 2008 Des 9-10; Nha Trang, Vietnam. Canberra (AU): Australian Centre for International Agricultural Research. hlm 85-88.

Dalsgaard, J., Lund, I., Thorarinsdottir, R., Drengstig, A., Arvonen, K., \& Pedersen, P.B. (2013). Farming different species in RAS in Nordic countries: Current status and future perspectives. Journal of Aquacultural Engineering, 53, 2-13.

Drengstig, A., \& Bergheim, A. (2013). Commercial land-based farming of European lobster (Homarus gammarus L.) in Recirculating Aquaculture System (RAS) using a single cage 
approach. Journal of Aquacultural Engineering, $53,14-18$.

Effendi, H. (2003). Telaah kualitas air. Yogyakarta (ID): Kanisius.

Endarko, Putro, T., Nuzula, N.I., Armawati, N., Wardana, A., Rubiyanto, A., dan Muntini, M.S. (2013). Rancang bangun sistem penjernihan dan dekontaminasi air sungai berbasis biosand filter dan lampu ultraviolet. Berkala Fisika, 16, 75-84.

Johnston, D., Melville-Smith, R., Hendriks, B., Maguire, G.B., \& Phillips, B. (2006). Stocking density and shelter type for the optimal growth and survival of Western Rock Lobster Panulirus cygnus (George). Journal of Aquaculture, 260, 114-127.

Kasam, Yulianto, A., dan Sukma, T. (2005). Penurunan COD (chemical oxygen demand) dalam limbah cair laboratorium menggunakan filter karbon aktif arang tempurung kelapa. LOGIKA, 2(2), 317.

Kuhn, D.D., Drahosb, D.D., Marsha, L., \& Flick Jr, G.J. (2010). Evaluation of nitrifying bacteria product to improve nitrification efficacy in recirculating aquaculture systems. Journal of Aquacultural Engineering, 43, 78-82.

Phillips, B.F., \& Kittaka, J. (2000). Spinny lobster: Fisheries and culture. Osney Mead (GB): Blackwell Science.

Pusat Pengkajian dan Perekayasaan Teknologi Kelautan dan Perikanan [P3TKP]. (2013). Laporan akhir penelitian rekayasa shelter untuk pendederan air laut. Jakarta: Kementerian Kelautan dan Perikanan.

Silaban, T.F., Santoso, L., dan Suparmono. (2012). Pengaruh penambahan zeolit dalam peningkatan kinerja filter air untuk menurunkan konsentrasi amonia pada pemeliharaan Ikan Mas (Cyprinus carpio). e-Jurnal Rekayasa dan Teknologi Budidaya Perairan, I(1), 47-56.

Spotte, H.S., (1996). Fish and Invertebrate Culture. Water Management in Closed System. New York (US): Willey Interscience.

Wickins, J.F., \& Lee, D.O.C. (2002). Crustacean farming ranching and culture. Blackwell Science Ltd.

Yudha, A.P. (2009). Efektifitas penambahan zeolit terhadap kinerja filter air dalam sistem resirkulasi pada pemeliharaan Ikan Arwana Sceleropages formosus di akuarium. Skripsi. Dept. BDP, FPIK, Institut Pertanian Bogor.

\footnotetext{
Uji Performansi Teknologi Recirculating Aquaculture System (RAS) Terhadap Kondisi Kualitas Air pada Pendederan Lobster Pasir Panulirus homarus - Lolita Thesiana dan Amin Pamungkas
} 
